\title{
Research on the Integration of the Winter Sports Travel Industry in Northeast Region
}

\author{
Zhang Dachun \\ ${ }^{1}$ P.E Departmentof Heihe College, Heihe Heilongjiang, China
}

Keywords: Integration, Winter Sports Travel Industry, Northeast Region

\begin{abstract}
The development of society makes people more desire and pursuit of winter sports tourism. From the geographical point of view, the four northeastern provinces (regions) vast, long winter, snow and ice resources are very rich, extensive winter sports items, many unique ethnic characteristics of snow and ice sports, winter sports is very suitable for the development of tourism. Northeast region with the development of winter sports and winter tourism industry in favorable conditions, I can be said, the winter sports tourism is a new industry, the development of related industries, and promote the rapid growth of the local economy. In the world, countries with winter sports tourism resources have generally developed winter sports-related tourism projects, and compete across the development trend.
\end{abstract}

\section{Introduction}

Winter sports tourism in Northeast winter most popular, one of the most fashionable tourist projects, especially in the four northeastern provinces of alpine skiing, ski every winter arrival of visitors, enthusiasts flock. Not only enhance the physical and mental health of citizens, improve quality of life, as well as the ability to promote regional economic development and has greatly enhanced the dominance of winter sports in the National Fitness.

Northeast region due to favorable geographical and climatic conditions became the main base of Chinese winter sports, relying on snow and ice, and actively implement the government-led development of snow tourism strategies. The snow tourism as a pillar industry to accelerate the development and construction of its industrial development environment has been further optimized, the four northeastern provinces of snow and ice tourism momentum of rapid development.

\section{The Concept of Winter Sports Tourism}

Winter sports tourism is one of the types of sports tourism, tourists travel by means of ice made in the body and mind in cultural activities and entertainment, physical exercise. I believe that the winter sports tourism has broad and narrow sense. Generalized snow sports tourism is the sum of the tourists in the ice and snow tourism engaged in a variety of mental and physical recreation, physical exercise, sports rehabilitation, sports competitions, sports and cultural exchanges, and snow tourism, sports tourism enterprises and social relations. Winter sports tourism is narrow in order to adapt and meet the needs of tourists and winter sports, and a variety of sports activities, give full play to a variety of functions to achieve mental and physical pleasure, physical exercise, harmonious development purposes and the rich social and cultural life kinds of social activities.

\section{Analysis on the Winter Sports Tourism Resource}

Natural Winter Sports Tourism Resources. In China, the winter sports tourism rich in natural resources. From the geographical position, the four northeastern provinces of snow tourism rich in natural resources, where the four seasons alternating seasons, long winter, snow and long, snow quality is good, the temperatures, ice and snow sports tourism has good natural environment. Among them, the ski resources are mainly concentrated in: Harbin, Heilongjiang province Yichun City, Mudanjiang City, the Greater Xing'an Mountains; Changchun City, Jilin Province, Jilin City; Shenyang City, Liaoning Province, Liaoyuan City, and the like. For example, the North Lake Yabuli 
Ski Resort and Ski Area is consistent with international standards of ski slopes. Ice, snow and ice tourism mainly in the city of Harbin in Heilongjiang, Mudanjiang, Qiqihar, Yichun, etc; Jilin City, Jilin, Changchun; Liaoning Shenyang, Dalian and other cities. In the Northeast, every city has artificial ice rink, natural ice rink and natural resort. Ecotourism in Northeast mainly snow forest adventure, forest, hunting, snow sledding. In addition, in our urban land in other provinces, there are varying periods of ice and snow tourism resources available for exploitation.

Humanities and Snow Tourism Resources. In snow sports, there are different times for our winter sports athletes make a significant contribution and they are our unique winter sports history and culture creators and Promotes. China has a large winter sports tourism base, such as Yabuli, North Lake and other internationally renowned ski resort. Asia's largest museum of local speed skating, ice hockey training hall and other tricks, have certain characteristics of winter sports venues and building facilities is the best combination of ice and snow scenery, science and technology, architecture and other arts, technology. Snow and ice on the human environment by tourists winter sports viewing, you can close contact with the snow sports and sports venues of cultural history, enjoy winter sports star style, you can feel the joy of ice and snow scenery humanities. Snow painting, snow sports memorabilia, sports equipment, sports sculptures, mascots and other winter sports art, contains a rich cultural characteristics of snow, ice and snow sports tourism for the development of human resources.

The Snow-Related Tourism Resources. On the 19th Winter Olympic Games, the famous athlete Yang Yang won the first ever Olympic gold medal, to achieve the Olympic gold medal "zero" breakthrough. At the 20th Olympic Winter Games, Han Xiaopeng won the men's freestyle skiing aerials gold medal, which is China's first men's gold medal in a Winter Olympics. The fact that snow spectator events, sightseeing tours, will further promote the rapid development of China's winter sports tourism.

Festivals Ice and Snow Tourism Resources. In the north or the southwest plateau region, the festival day, many festivals. For example, "Harbin International Ice and Snow Festival" is the history of a regional festival of snow and ice for the content of the festival each year beginning January 5, during the festival are: Fair ice, snow Fair, ice Fair winter fashion show, snow soccer, winter swimming, skiing, skating and other series of activities with local characteristics sports culture, trade and economic activities, high grade, thick and so fun. Yabuli is not only the first choice for international events, but also quite distinctive snow resort, the first China Heilongjiang International Skiing Festival in 1998, which makes winter sports tourism has made great progress, economic and social benefits are extremely impressive.

\section{The Integration of Tourism Resources}

On the system integration of resources is a way of thinking and the basic idea is to resources as a system, through the various elements of the system and restructuring process to make contact with each other, mutual penetration, form a rational structure, to achieve overall optimization, coordination development, play the overall maximum function, to achieve the overall maximum efficiency. At present the integration of tourism resources connotation both broad and narrow understanding, broad integration of tourism resources in the region include food tourism, housing, transportation, travel, shopping, entertainment six elements of the integration between enterprises, the organic integration of various types of tourism resources aspects, integration of tourism between enterprises and the like; narrow understanding refers to the integration of various types of tourism resources. According to the main object of this study, integration of tourism resources focused primarily on narrow areas. Integration of tourism resources mainly refers to the narrow sense of resource managers and tourism operators and tourism in accordance with the overall objective of market supply and demand situation of the regional tourism development, with the legal, administrative, economic and technical means, the various combinations of elements related resources into a unified overall function, enabling the process to maximize the market value of the regional tourism resources and maximize the overall efficiency.

Integration is a means of win-win situation, the implementation of integration of tourism 
resources of the fundamental purpose is to realize the benefits of tourism in the region complementary to enhance the overall tourism competitiveness. According to tourism resources exists symbiosis, the integration of tourism resources can be divided into different types of integration of integration of tourism resources and tourism resources of the same type.

\section{The Northeast Region Snow Tourism Resources Integration Conditions}

With the further development of tourism, the primary development of tourism resources can not meet the needs of tourists, tourism resources connotation urgent need to dig and redevelopment. Northeast regional tourism development, especially the development of winter tourism for regional economic development has made a significant contribution to the future will continue to adjust the industrial structure, increase employment opportunities and expand the important role of opening up. So break regional boundaries through the winter ice and snow tourism resources integration, reconfiguration and portfolio resources, tourism resources for the realization of regional advantages brand, maximize the benefits of tourism it has important strategic significance.

The Real Necessity. At present, the ice and snow tourism has been widely carried out in the northeast, north, northwest, and even in the south, the snow around have played cards, compete for ice and snow tourism market. Although the Northeast region snow tourism due to the advantages of natural conditions, regardless of size or influence the development level in the country are far ahead, but with the restriction of high-tech development, geographical conditions decreased, showing a wide range snow tourism trend of Northeast regional tourism development a threat of snow and ice. Since the Northeast region adjacent geographical units and similar historical heritage and become a relatively independent economic region, with the national revitalization of old industrial bases in Northeast China, regional economic integration trend will become more apparent from the coordination, integration angle regional tourism elements configured tourism spatial layout has become an inevitable tourism development. Thus, through the optimal combination of ice and snow tourism resources, tourism resources will be integrated into the overall ice Release conducive to economies of scale, improve product quality, occupy a higher grade of similar tourism resources, while snow and ice resources within the region complementary advantages, can enhance the product features and taste, appeal to expand, and ultimately enhance the competitiveness of products.

The Objective Possibility. Northeast region as the main areas of implementation of the strategy of revitalizing the northeast, will be following the Pearl River Delta, Yangtze River Delta, the Bohai Sea region's fourth largest economic zone, good economic base of tourism development, more perfect supporting facilities ice and snow tourism in the country has a monopoly, improve the formation of the Commonwealth of the Northeast regional tourism regional tourism more powerful foundation.

"Building Northeast travel pattern" has become an inevitable trend in the Northeast Region Tourism Cooperation, Northeast regional tourism cooperation has been the first "4 Northeast Regional Tourism Cities Commonwealth" to become a "4 +1 city in Northeast regional tourism association." Tourism consortium has together to create the image of a tourist destination, tourism product launch, promotional collaboration features such as the Northeast region snow tourism resources can make use of the partner organizations, led by the core of the city, using established resources, markets, and other information exchange network for snow tourism product restructuring, optimization become more competitive regional tourism brand.

The integration of cultural differences snow tourism resources of the foundation. Cultural differences are an important prerequisite for snow tourism resource integration, integration is not assimilation and the difference will remain a major factor in the formation of tourist attraction. Northeast Regional in the historical development of inclusive absorb indigenous culture, Central Plains culture and foreign cultures three cultures form a unique gene Kanto culture, but there are differences within the region around because of the different regional characteristics and the course of history, culture, this difference and snow tourism resources combined, will further enhance the level of snow tourism products, so that the content of ice and snow tourism products more abundant. 


\section{Measures of Integration of Northeast Regional Ice and Snow Tourism Industry}

Snow is important to characterize the Northeast regional tourism image, whether Heilongjiang China / cool0 Province, China ski resorts in the 21st century, rime ice Jilin Province, the truth Jilin, or snow Spa World in Liaoning Province, have demonstrated the ice element of regional tourism core position. Ice and Snow Tourism resources belong to the nature of the weather, climate class tourism resources, tourism resources in the region to develop into a higher level, more competitive tourism product and it must be combined with the regional culture. Kanto culture as a fusion of indigenous cultures, the Northeast region of the Central Plains culture and foreign culture, cultural characteristics has penetrated in all aspects of people's life and production. Therefore, it should be combined with regional cultural characteristics of snow and cultural relations snow and history, snow and Folklore, snow and buildings, snow and other industries to refine, generalize to highlight the region snow tourism status, show the rich cultural connotation of the snow tourism image .

The overall image characteristics, combined with the monomer snow tourism resources used by the "ice" and "snow" of two parts, from the Northeast region snow tourism development point of view, does not make a distinction between their respective advantages in resources snow, ice and snow tourism culture connotation yet to be excavated, the cultural value of the winter tourism resources has not been fully translated into practice values, culture and ice arena has advantages tend to have a more effective competitive force.

\section{Conclusion}

The Northeast because of its unique geographical conditions and historical and cultural landscape, sports become rich tourism resources of the region, the development of sports tourism industry also earlier, but from a regional industry Overall, there is a fragmented and inadequate development caused inefficient use of resources, regional characteristics is not obvious, the market disorder and other problems, so that resources in Northeast China's sports tourism industry as a whole has not been played, lack of core competitiveness, restricting its development, it is necessary through integration, increase development efforts to achieve the optimal allocation of resources, and strengthen the overall force of industrial development, shaping the regional sports tourism image and promote its rapid development, to revitalize the old industrial base to play its due role.

\section{Acknowledgment}

The humanities and social sciences research project of Ministry of education in 2014 (Research on the construction of ice and snow sports tourism industry cluster in Northeast China, No.14YJA890016)

\section{References}

[1] Huifang Zhou: Economic Geography, Vol. 6 (2014) No 53, p.25-26

[2] Hongli Zhang: Business management, Vol. 12 (2015) No 27, p.74-76

[3] Qin Guo: Northeast Normal University, Vol. 1 (2013) No 33, p.11-14

[4] Jieming Liu: Tourism Tribune, Vol. 3 (2013) No33, p.121-124

[5] Qin Guo: Human Geography, Vol. 1 (2011) No 33, p.11-14 